in conjunction with similar data gathered by the forty-six other co-operating countries with the view of obtaining fuller insight into the synchronous largescale events in meteorology, magnetism and aurora, over the earth and in the atmosphere up and into the conducting layers. A large amount of material is also available for the study of the interrelationships among the varied phenomena observed and recorded during the year's activities.

\section{The New Coast-line of Antarctica}

FURTHER information has come to hand concerning Consul L. Christensen's discoveries in the Antarctic referred to in Nature of March 17, p. 409. Princess Astrid Land, as it was named, is now reported in the Times to lie in about long. $86^{\circ} 45^{\prime} \mathrm{E}$. and a little south of the Antarctic Circle. This is to the west of and adjoining Kaiser Wilhelm Land, discovered by Dr. E. von Drygalski in 1902, and east of Princess Elizabeth Land, discovered by Sir Douglas Mawson in 1931. The land was sighted from an aeroplane from a distance and reported to rise for a distance of about 150 miles. It is further reported that the Douglas Islands, off MacRobertson Land, do not exist. Consul Christensen then took the Thorshavn eastward and reports that in lat. $71^{\circ} 44^{\prime} \mathrm{S}$., long. $134^{\circ} 11^{\prime} \mathrm{E}$. (? W.) his seaplane could find no land to the south. Proceeding via Peter Island, the ship rounded Cape Horn, discovering a new bank to the south, and made for Montevideo. A number of soundings were taken in hitherto uncharted waters.

\section{Early Science in Poland}

A STUDY of the development and position of science in Poland up to the end of the sixteenth century is given by Prof. Kazimierz Dobrowolski in the recent issue of Nauka Polska (vol. 17 ; 1933), an annual publication devoted to the organisation and progress of science in Poland. Prof. Dobrowolski's account (132 pages) of Poland's contributions to early science is especially detailed for the sixteenth century itself and is well documented throughout. It refers not only to the natural sciences, so far as they had then developed, but includes also incursions into theology, philosophy, logic, law and history. It is evident that 'science' as understood in Poland, and in Europe generally for that matter, up to the seventeenth century was closely associated with alchemy, astrology and occult practices. But towards the close of the period under review, Prof. Dobrowolski points out that real scientific inquiries were being prosecuted in Polish centres of learning, so far as political upheavals permitted. The work of Copernicus is not only important in itself but also because it was followed by that of Francis Bacon, Galileo, Descartes and others. Early English and French contributions to scientific knowledge, for example, Roger Bacon's discoveries and writings and those attributed to Thomas Aquinas, had reached Poland and exerted some influence upon thought there. The same volume of Nauka Polska contains some notes by Dr. M. Wolfke on certain recent developments in pure and applied physics and another contributor describes life in scientific circles at Lodz.

\section{High-Voltage Testing Equipment}

Economical considerations are leading electrical engineers to use very high voltages for transmitting electrical energy over long distances. The accessories used with high-voltage cables or overhead lines require to be specially tested. This has made it necessary to build high-voltage laboratories and to design insulating devices which will withstand these high pressures. In the early days of testing, the perfection of a testing set was judged mainly by the length and appearance of the spark and the loudness of the noise it made. Nowadays these measurements have to be made with high accuracy in accordance with stringent specifications. On the result of the acceptance tests, errors of a few per cent may turn the scale for rejection, leading to losses of thousands of pounds to the manufacturer. In certain cases discrepancies of ten per cent are shown in the results obtained in different laboratories, leading to considerable dissatisfaction.

IN a paper on high-voltage testing read on December 21 to the Institution of Electrical Engineers by B. L. Goodlet, of the Metropolitan Vickers Electrical Co., Ltd., it is shown that the discrepancies are mainly due to badly designed equipment and insufficient knowledge of the performance of the testing set under various conditions. They also arise sometimes from differences in the technique used in testing. Single units for testing purposes are usually built for a million volts, but it is often more advantageous to utilise the well-known cascade connexion which produces the required total voltage by adding up the individual voltages of several smaller units. The high voltage and low power rating of these transformers lead to difficulties in designing them. The authors illustrate this by showing oscillographic records of the distorted wave forms of the current and voltage sometimes obtained. In the third part of the paper a complete mathematical and experimental discussion is given of the impulse generator.

\section{Economic Survey of Agriculture in the East of England}

As excellent economic survey, the second of the series, based on a sample of more than a thousand farms, has recently been published (University of Cambridge: Department of Agriculture, Farm Economics Branch. Report No. 21 : "An Economic Survey of Agriculture in the Eastern Counties of England, 1932". Pp. vi +89 . Cambridge : School of Agriculture, 1933. 2s. 6d. net). As a record of what is actually happening to the individual units of agriculture in the eastern counties of England, it could scarcely be bettered. Reality is an excellent antidote to indiscriminate theorising in any subject; surveys such as this enable the hard facts of an industry of small units like agriculture to be ascertained. Without a factual basis of this type there can be no sound future planning or adequate criticism of past planning.

The broad facts revealed by the survey are sufficiently disquieting. The depression of agriculture 
is common knowledge; here the extent of the depression is measured. Except for the wheat deficiency payments, the year 1932 appears to have been even worse than 1931. Of the individual farms the most profitable are the most progressive, those which aim at a high level of productivity and low labour costs per unit output; but specialisation, which would lead to the most complete mechanisation, is unsuccessful, for labour and by-products cannot be efficiently utilised. The general purpose farm is the one most adapted to economical production. The whole report gives a picture of economic laws striving to operate, but without their natural consequence, the elimination of the least efficient. The moral of it all is plain : overproduction of food. Whether the English farmer should be allowed to suffer as a result of what is after all a world phenomenon is a matter of politics. What is abundantly plain is that salvation is only to a very limited extent in his own hands. Mere increase in efficiency is patently not enough. In fact such increase, if world wide, will merely aggravate the disease.

\section{Recent Research in Building Practice}

THe annual report of the Building Research Board for 1933 (London : H.M. Stationery Office, 2s. 6d. net) contains an account of several interesting investigations. The failure of lime-plaster ceilings on lathing, whilst of frequent occurrence, is not generally die to defective materials, but to hasty work and disturbance by other types of work in the building at a time when the plaster ceilings are very sensitive to vibration. Damp walls are often caused by penetration of rain through fine cracks between the bricks and mortar. Most colourless waterproofing materials are ineffective, but an imitation stone paint showed a good resistance to weathering. Experiments on heating showed that intermittent heating from 9.30 a.m. to 5.30 p.m. required only three quarters of the electrical energy for continuous heating, although the latter method has been said by heating engineers to be equally economical. Testing of bricks by exposure, and of concrete piles by an ingenious piezoelectric method, are described.

\section{Science Abstracts}

THE issue of the two index parts of Science Abstracts completes the physics and the electrical engineering volumes for 1933. More than 260 periodicals are dealt with by the editor and his 71 abstractors for physics and 57 for electrical engineering. Each volume has between 30 and 40 more pages than the volume for last year. 5,491 abstracts of average length 0.247 page relate to physics and 3,078 of average length 0.257 page to electrical engineering. In each case the average length is nearly the same as last year. Reference to the abstracts is greatly facilitated by the extensive indexes provided. In the physics volume the subject index covers 208 pages and there is a key to the subject index of 15 pages and an author index of 76 pages. In the electrical engineering volume the subject index has 109 and the author index 45 pages, but there is no key. Each volume seems indispensable to the physicist or to the electrical engineer who wishes to keep himself up to date, but while every member of the Physical Society and possibly of the American Physical Society gets a copy of the physics volumes the Council of the Institution of Electrical Engineer, reported in May last that only 9 per cent of its members subscribed for copies of the electrical engineering volume.

\section{German Association of Men of Science and Physicians}

ThE German Association of Men of Science and Physicians (Gesellschaft Deutscher Naturforscher und Ärte) is modifying its policy with the view of overcoming excessive specialisation. It is proposed to emphasise the tasks and problems common to many or all branches of science and medicine, and to promote discussion on these common topics on the widest possible basis. The annual meeting of the Association will last not more than three and a half days. The Council of the Association will only arrange the general sessions, the main group and joint sessions, and popular evening lectures. The general sessions will be devoted to topics in which some definite results have been reached or to problems of immediate importance. If discussion does not follow these addresses by selected speakers, the same theme may be handled more freely in joint sessions of sections. The Council will abandon the attempt to arrange meetings of the separate sections, leaving them to deal individually with the local committee. It has been the custom for some years past that allied and associated societies should meet at the same place, and either before or after the formal meetings of the Association. This custom is to be continued at the next meeting in Hanover (Sept. 16-20, 1934), and with the help of the local committee. An innovation is the Zweckverband of German scientific and medical congresses, the aim of which is to maintain contact between these congresses so that whilst specialisation goes forward they shall not be shut off from each other. The purpose of this union is to publish the dates, places and programmes of these congresses; for example, various medical congresses take place in April and May next.

\section{Royal Geographical Society's Awards}

His Majesty TeE King has approved the award of the Royal medals as follows : Founder's medal to Mr. Hugh Ruttledge; for his journeys in the Kumaon and Garwhal Himalaya extending over eight years and his leadership of the Mount Everest Expedition, 1933 ; Patron's medal to Capt. Ejnar Mikkelsen, for his explorations in the Arctic between 1900 and 1912 and for his work in Eskimo re-settlement on the east coast of Greenland. The Council has made the following awards: Victoria medal to Mr. Edward Heawood, for his work on the history of geography and cartography and his devoted service to the Society as its librarian; Murchison grant to Mr. John Rymill, for his work in Greenland and leadership of the party after the death of Mr. H. G. Watkins on his second expedition; Back grant to Dr. D. N. 